DOI: $10.17805 / z p u .2016 .4 .11$

\title{
Старообрядцы Николаевска: адаптация или ассимиляция в светских условиях США?*
}

К. М. ТОВБИн

(ЮЖНО-САХАЛИНСКИЙ ФИЛИАЛ РОССИЙСКОГО ЭКОНОМИЧЕСКОГО УНИВЕРСИТЕТА

ИМ. Г. В. ПЛЕХАНОВА),

А. В. СЕМИЧАЕВСКИЙ

(ЦЕНТРАЛЬНАЯ ГОРОДСКАЯ БИБЛИОТЕКА ИМ. О. П. КУЗНЕЦОВА, Г. ЮЖНО-САХАЛИНСК),

В. В. СОКОЛОВ

(НЕЗАВИСИМЫЙ ИССЛЕДОВАТЕЛЬ, Г. ЮЖНО-САХАЛИНСК)

Старообрядцы Аляски являют собой пример приспособления традиционных духовных принципов к условиям пребывания в центре мировой глобализации, вестернизации, научно-технического прогресса и постиндустриализма. Старообрядческий опыт неагрессивного сопротивления миропорядку, затирающему любые этнические, культурные и конфессиональные разграничения, чрезвычайно важен при прочерчивании русского цивилизационного пути в современных условиях.

С целью изучения этого опыта авторами было проведено исследование образа жизни и менталитета русских старообрядцев штата Аляска (США). Проведенная в октябре 2015 г. экспедиция вскрыла в жизни староверов Николаевска тесное переплетение остаточного мировоззренческого традиционализма, либерализующейся социальной сферы и радикального ментального модернизма. Все это заставило предположить беспомощность традиционного православия перед натиском секулярных реалий США. В статье проведено сравнение проблем николаевской старообрядческой диаспоры с аналогичными проблемами староверов-беспоповцев юга Аляски, с бо́льшим успехом сохраняющих свою самобытность, но также поддающихся секуляризующему воздействию американской повседневной культуры.

Выявлен культурный и духовный упадок аляскинского старообрядчества, а также зафиксирована мощь американского консюмеризма, который растворяет особенности иммигрантских диаспор, в то же время сохраняя их внешнюю оригинальность и приумножая американскую субкультурную множественность.

Ключевые слова: старообрядчество; староверы; православие; диаспора; США; Аляска; Николаевск; полуостров Кенай; адаптация; ассимиляция

* Исследование выполнено при поддержке РГНФ (проект «Русские старообрядцы в Северной Америке: национальная идентичность в эпоху глобализации», грант № 15-03-18037-е).

The study was performed at the Russian Plekhanov University of Economics with the support of the Russian Humanitarian Foundation, the project 15-03-18037-e «Russian Old Believers in North America: national identity in the era of globalization». 


\section{ВВЕДЕНИЕ}

Dусское старообрядчество является одним из ярчайших явлений русской традиционной культуры и в этом плане является объектом многочисленных исследований. Однако мало исследований посвящено феномену эмигрантского староверия - уникального примера адаптации исконно русской культуры к условиям совершенно чуждого культурного пространства. Сегодняшние старообрядцы Аляски являют собой пример приспособления традиционных духовных принципов, в хранении которых и заключается сущность старообрядчества, к условиям пребывания в центре мировой глобализации, вестернизации, научно-технического прогресса и постиндустриализма. Старообрядческий опыт неагрессивного сопротивления миропорядку, затирающему любые этнические, культурные и конфессиональные разграничения, чрезвычайно важен при прочерчивании русского цивилизационного пути в современных условиях. Задачей данного исследования является комплексное исследование мировоззрения, менталитета, образа жизни аляскинских старообрядцев.

В рамках исследования наш исследовательский коллектив в октябре 2015 г. побывал в штате Аляска, США. Начальным пунктом было поселение Николаевск-на-Аляске в центральной части полуострова Кенай.

Николаевск был первым старообрядческим поселением на Аляске с 1968 г. (Калугина, 2009: 680; Фефелов, Гашкова, 1999: 5). История заселения Аляски староверами вполне подробно отражена Ю. В. Аргудяевой и А. А. Хисамутдиновым (Аргудяева, Хисамутдинов, 2013; Аргудяева, 2012, 2014а; Хисамутдинов, 2011), а также другими исследователями (Гортер, 2015; Попова, 2015). Поскольку историческая и этнографическая стороны старообрядческой жизни на Аляске изложены более чем подробно, наша исследовательская группа обратилась к культурологической и этнопсихологической сторонам исследования. Однако исторический контекст в нашей работе продолжал присутствовать, и в его рамках нами было сделано определенное открытие. Согласно общепринятой точке зрения, опирающейся как на исторические описания, так и на свидетельства самих староверов (Фефелов, Гашкова, 1999: 5), инициатива заселения Аляски принадлежала старообрядцам. Но документы, просмотренные и скопированные нами в архиве университета «Аляска Анкоридж» (University Alaska Anchorage), показывают первичность инициативы совершенно других участников Толстовского фонда ${ }^{1}$ и муниципальных властей боро ${ }^{2}$ Кенай Пенинсула, не только пригласивших староверов на занимаемые ими земли, но и всемерно участвовавших в их переезде и обустройстве. Об этом факте упоминает Аргудяева (Аргудяева, 2014а: 56; 2012: 15). Наша исследовательская группа подтвердила его, работая с архивными материалами. Факт этот - умалчиваемый староверами или не знаемый ими - весьма важен, так как дополняет доказательства принципиальной социальной пассивности православных, их тотальной зависимости от государства, даже если речь идет о столь внешне антигосударственническом и автономистском тренде, как русское старообрядчество.

В остальном наши исследования носили культурологический и религиоведческий характер; мы анализировали повседневность старообрядцев, их нахождение меж нескольких культурных линий: традиционная (древлеправославная), русская и американская. Важно было пронаблюдать меру выживаемости традиционной русской культуры и православной ментальности в условиях американского социокультурного господства. 
СТАРООБРЯДЦЫ ААЯСКИ

Следует отметить, что аляскинские староверы - единственные деревенские старообрядцы США, что в некоторой мере обусловливает их пафос и особое место в старообрядческой среде Северной Америки. Переселились староверы в основном из пригородов Портленда и Вудберна (штат Орегон) - в стремлении отдалиться от угрозы ассимиляции со светской американской действительностью (Хисамутдинов, 2015: 41). Николаевск заселялся с 1968 г., первыми насельниками были четыре семьи: Калугины и три ветви рода Мартюшевых. Основным занятием изначально было огородничество, а место фермерства быстро заняли рыболовство и судостроение. Справедливости ради надо отметить, что сельское хозяйство староверов было не самодостаточным и в Орегоне, и в Бразилии (куда староверы переселились ранее, а затем переехали в Орегон) - основной достаток давали занятость на мебельных фабриках или батрачество на фермах крупных местных землевладельцев. Начало реструктуризации старообрядческого хозяйства было положено еще до переселения на Аляску.

Основным событием в истории старообрядчества Аляски было принятие священства белокриницкой иерархии 3 в 1983 г.

Небольшая справка. После церковного раскола XVII в. большинство староверов беспоповцы - не признали легитимности духовенства официальной церкви, полагая, что всем миром (и обновленной церковью) ныне правит антихрист. Также они не имели собственного епископата для рукоположения в священство, а дораскольные священники-староверы постепенно вымерли. (Их оппоненты-староверы, вынужденно принимавшие в свои общины беглых священников, именовались беглопоповцами.) Ключевым следствием такой установки было отсутствие всех таинств, которые может совершать православный священник, кроме крещения, которое может совершать и мирянин. Поскольку для православной духовной жизни необходимо совершение таинств (причастия, венчания, исповеди, соборования и пр.), вопрос отсутствия таинств всегда был наиболее болезненным для беспоповцев, вынуждая их неустанно искать «неповрежденное священство», т. е. отдаленную поместную церковь, сохранившую духовенство и не поддавшуюся литургическим обновлениям, как в России и Греции. Обсуждение вариантов принятия духовенства, равно как и практика бессвященнической духовной жизни, всегда были поводами для расколов в беспоповской среде на согласия либералов (напр., поморцев) и маргиналов (напрю, старопоморцев-федосеевцев).

Ао этого момента все староверы - выходцы из Бразилии и Орегона принадлежали к специфическому согласию часовенных, «вынужденно» принадлежавшему к беспоповскому толку (Злобин, 2005: 23; Софроний, 1999: 6), т. е. существующих без духовенства не из богословского принципа беспоповцев (невозможность священства в антихристовом мире), а по причине вымирания собственных благочестивых пастырей. Таким образом, часовенные не разделяли особенностей беспоповской догматики (представления о «духовном антихристе», «замирщении», «мирском священстве», двойственности в отношении к институту брака, т. е. его отрицания и вынужденного дозволения как «греха») и придерживались поповской мировоззренческой линии, за исключением наличия собственного духовенства. За неимением епископата священство у часовенных иссякло, но в отличие от поморцев или федосеевцев они не провозглашали наступления «духовного антихриста» и отсутствия само́й возможности духовенства, продолжая искать «неповрежденных попов» в разных православных юрисдикциях, старо- и даже новообрядческих. В то же время сходство литургической и повседневной культур часовенных и «классических» беспоповцев (поморцев и фе- 
досеевцев) привело к заимствованию первыми у вторых значимых деталей богословского самоопределения и, как следствие, менталитета и поведенческих моделей.

С другой стороны, тема «вынужденного» беспоповства и идея ненайденного «потаенного священства» в согласии часовенных (до 1917 г. самом большом в России) продолжала быть актуальной всегда и всегда решалась по-разному. Находясь в Америке в годы холодной войны, они были вынуждены искать духовенство за пределами СССР и нашли для себя вариант в виде Румынской (Браильской) митрополии Русской православной старообрядческой церкви (белокриницкая иерархия). Выбор обусловливался наличием родственников-поповцев в Румынии; эта же причина повлияла на выбор первого американского священника - Конрада Фефелова в 1983 г. (Фефелов, Гашкова, 1999: 5).

Но специфика старообрядческого и, в частности, поповского отношения к таинству крещения привела к серьезному и усиливающемуся со временем расколу в среде николаевских староверов. Конкретно: румынские поповцы поставили под сомнение правомочность «мирянского» крещения, совершенного над некоторыми николаевцами. Православное богословие допускает бессвященническое исполнение таинства крещения «страха ради смертного», но к личности такого исполнителя могут быть предъявлены весьма строгие требования, а некоторые фундаменталисты, типичные для старообрядческой среды, могут довести эти требования до невыполнимости. Так, некоторые авторитетные старики были признаны некрещеными, это привело к серьезным скандалам и конфликтам, и, как следствие, только 20\% старообрядцев присоединились к поповству, остальные остались беспоповцами, но уже принципиальными. Раскол прошел через семьи, затрагивая личные, имущественные, земельные и ментальные интересы. Обычный для староверов догматический склад мышления и унаследованные из России непримиримость и максимализм привели после принятия священства к криминогенной обстановке в Николаевске и вынужденному переселению принципиальных беспоповцев на иные территории Аляски - в первую очередь на юг полуострова Кенай, где возник особенный беспоповский социокультурный анклав. По словам некоторых очевидцев тех событий, напряженность взаимоотношений периодически приводила даже к использованию огнестрельного оружия. Некоторые николаевцы-беспоповцы переселились на юг, бросив свои дома и земли - пустующие жилища и ржавые автомобили по сей день напоминают о том исходе.

\section{СТАРОВЕРЫ НИКОААЕВСКА}

Поскольку для косных часовенных нововозникшие поповцы стали однозначными еретиками, вопрос о семейной связи с ними стоять не мог. Соответственно, поповское меньшинство не смогло брать женихов и невест в среде староверов не только Аляски, но и Орегона и почти всей Аатинской Америки, заселенной почти исключительно беспоповцами (Аргудяева, 2014b; Теплоухова, 2013). Вследствие этого начались (и продолжаются по сей день) смешанные браки с этническими англо-американцами, мексиканцами, индейцами и коренным населением Аляски. Эти супружества привели к полному уничтожению русского языка в среде старообрядческой молодежи Николаевска, к отходу от традиционного русского семейного уклада и бытоустройства к почти повсеместной «американе» 4 как образу жизни. В среде поповцев стали часты такие социальные отклонения, как алкоголизм, наркомания, разводы и домашнее насилие. Это можно считать социальными последствиями травматичного перехода из русскостарообрядческого культурного пространства в современное американское. 
Сегодня посещаемость Никольского храма чрезвычайно мала, богослужения проводятся на церковнославянском языке, который понимается только старшим поколением - поэтому священник вынужден читать проповедь по-английски. К примеру, наша исследовательская группа полностью отстояла праздничное богослужение на один из важнейших для православных праздник - Покров Богородицы (14 октября); в храме присутствовало около 20 человек, из которых язык службы был внятен менее чем половине. Некоторые прихожане были явными «пришельцами» из иных сред: мы видели татуированных латиноамериканцев в русских рубахах, слышали чтение чтецов, произносивших: «Господи, помилуй найс». По завершении литургии все прихожане незамедлительно покинули храм, не было никакой совместной трапезы или общения.

Все браки с иноверцами заключаются только в церкви и только после их крещения и формального воцерковления; однако почти $80 \%$ современных браков оканчиваются разводами, по свидетельству священника Николы Пименовича Якунина и его брата, старосты села Виктора Пименовича Якунина.

В трудовом отношении староверы Николаевска повсеместно отказались от изначального сельского хозяйства и перешли на рыболовство, вовлекшее их в множественные экономические связи с иноверцами и муниципальными властями. Эти связи со временем все более крепнут, а традиционная старообрядческая артель все более распыляется. Это второй по важности фактор потери староверами традиционной идентичности. Моральные дилеммы, повсеместно сопровождающие капиталистическое хозяйствование, трудно разрешимы в родственной среде.

Семейный уклад староверов претерпел существенные метаморфозы. Почти все женщины работают (правда, больша́я часть - на дому), выстраивая собственные карьеры и формируя собственный вклад в семейный бюджет - это прямой путь к равноправию и эмансипации, к уничтожению традиционной, домостроевской семейной этики. Почти каждая женщина имеет свой «бизнес», в который не вмешивается супруг, свой автомобиль, круг общения и мировидения. Семья, таким образом, строится как современное нуклеарное партнерство, признаком которого является (помимо вышеупомянутых разводов) малодетность, отличающая молодые семьи от старших поколений. В свою очередь, малодетность намекает на главнейшего демона православной социальной критики - планирование семьи, ставшее нормой для религиозных потомков Аввакума.

Все дети Николаевска обучаются в средней муниципальной школе по светской программе, в которую родители, как правило, не вникают. Изучение русского языка, сокращаясь в объеме с каждым десятилетием, пришло ныне к минимальному уровню; в нынешнем 2016/2017 учебном году предполагалась полная отмена обучения русскому языку. Юное поколение Николаевска не знает русского языка; даже храмовые чтецы-подростки не имеют представления о значении церковнославянских текстов, которые они проговаривают во время богослужения. Это беспокоит стариков-староверов, но проблема никак не решается.

Аля сравнения, старообрядческие сообщества юга Кенайского полуострова, отпочковавшиеся от николаевцев, вполне преуспели в решении этой проблемы: русская речь привита там в домашнем обиходе, слышна в безнадзорных детских компаниях. Та проблема, которая для поповцев Николаевска неразрешима и чревата гибельными социальными последствиями, староверами Хомера вполне разрешима. Хомерцы сохранили бодльший контроль за своими детьми, часто практикуют домашнее обучение, име- 
ют две собственные школы (это позволяет устранить детей от ювенального контроля муниципальных школ). Одна из основных причин большей традиционности южноаляскинских староверов - их больша́я численность и инкорпорированность в беспоповскую среду Северной и Южной Америки; это позволяет заключать брачные союзы только внутри старообрядческого сообщества, не идя на смешанные браки (как в Николаевске), чреватые вынужденными межэтническими компромиссами и секулярной толерантностью. Приняв в 1983 г. священство, поповцы Николаевска стали «еретиками» почти для всей беспоповсой диаспоры США, Канады и Аатинской Америки. В силу своей малой численности и конфессионального одиночества они вынуждены заключать браки с американцами или коренными народами Аляски. Хотя будущие супруги в этом случае формально принимают старообрядчество, такие браки обречены на англоязычность, утрату мужской патриархальности, ориентированность на светское пространство США, повышение детской и юношеской автономии и, как следствие, разрушение традиционного православного уклада.

Огромное значение для детей и их родителей имеет ювенальная практика в школе Николаевска. Инциденты выяснения отношений родителей с детьми, за которыми последовал отъем детей органами опеки в 1990-2000 годы, стали негативными примерами для всех жителей бывшей столицы старообрядцев Аляски. По этой причине телесные наказания в Николаевске не применяются, и родители, представляющие патриархальную модель воспитания и не навыкшие в современной педагогике, лишены способов контроля за подрастающим поколением. Аети завязаны на собственную среду (как в гетто крупных городов), родители контролируют только то, что, по сложившемуся у них мнению, определяет поведение, - одежду и формальные посещения храма. Это еще одна причина социальных аномий и культурной дезориентации Николаевска.

Все заботы о сохранении русской культуры Николаевска практически монополизированы единственной учительницей русского языка из Хабаровска Ниной Фефеловой (невестка первого николаевского священника), которая свела школьную активность к минимуму и сосредоточилась на собственном магазине сувениров и экзотики. Некоторые насельники Николаевска возлагают вину за упадок русской программы лично на деятельность Нины Фефеловой. Отсутствие институционализации русскоязычной социализации и привязка этой проблемы к индивиду - дополнительный признак уязвимости идентичности.

Следует отметить отсутствие торговой этики у русских староверов: при любой возможности они завышают цены, допускают обман, лукавство и давление на покупателя, используют любые возможности для продвижения собственных товаров или услуг - например, превращение стандартного американского почтового отделения в фактический гипермаркет. Солидная и устоявшаяся за столетия культура американского магазина у николаевских староверов вошла в компромисс с культурами рынка и ярмарки, унаследованных из провинций России.

Староверами Николаевска полностью копируются у американцев дизайн жилищ, планировка территорий, домашняя обстановка (включая телевизоры со спутниковыми антеннами, игровые приставки и компьютеры с подключением к Интернету), марки автомобилей и отношение к ним, способы организации досуга (от барбекю до семейных выездов на пляжи теплых стран). В Николаевске присутствуют, помимо школы, и иные атрибуты американской сельской действительности: почта, водокачка, пожарный участок; полицейский, совершающий регулярные объезды. За исключени- 
ем так называемого кафе (на деле - сувенирного магазина) Нины Фефеловой и единственного оформленного по-русски дома, ничто не выдает в этом поселении русского и православного. Исключение не составляет даже храм - он выполнен по внешним лекалам, характерным для протестантского молитвенного дома; присутствующие в его дизайне элементы православного декора также не чужды современной американской действительности, принявшей в наши дни моду на греческое православие.

Однако господство «американы» не мешает староверам и даже их детям одеваться в русские рубахи и сарафаны. Замужние женщины непременно носят отличительный головной убор - кичку (весьма упрощенную и оставляющую часть волос открытой). Все мужчины с юношества непременно носят бороды. Впрочем, это также укладывается в американскую мультикультуралистскую логику, приветствующую субкультурное своеобразие, которым маскируется тотальная вовлеченность в кредитно-финансовую и хозяйственную системы.

Таким образом, Николаевск не имеет ничего общего с русской деревней, тем паче - со старообрядческим селом, описаниями которых прославились некоторые российские писатели. Это типичное американское county ${ }^{5}$, имеющее большое сходство с постиндустриальным пригородом. Такое положение укладывается в нынешнюю американскую социальную стратегию рурализации 6 , опирающуюся на высочайшее качество североамериканских дорог, автомобилей, оптоволоконных линий и систем спутниковой и мобильной связи.

Несомненно, эти черты, во многом бывшие последствиями вынужденного брачного либерализма поповцев, повлекли за собой фундаменталистский отклик со стороны более традиционно ориентированных беспоповцев. Беспоповцы в силу своей численности не испытывали проблем ни с семейными, ни с трудовыми связями, поэтому имели возможности для построения собственных местообитаний на более традиционалистических основаниях, затруднявших ассимиляцию в американской среде. После принятия священства некоторыми насельниками Николаевска и последующего усиления криминогенной обстановки многие староверы выехали на юг Аляски, в окрестности г. Хомер (Моррис, Моррис, 2009: 117). Ао сих пор некоторые представители старообрядческих сообществ южного Кеная характеризуют николаевцев как «разбойников», проводя соответствие между принятием священства, упадком русского языка и культуры, смешанными браками, семейным насилием и распространенным в Николаевске пьянством.

\section{ЗАКАЮЧЕНИЕ}

Таким образом, за видимостью высокого американского достатка, внешне выражающего солидность и устойчивость образа жизни, скрываются весьма противоречивые процессы. Вместо адаптации или консервации национальной культуры и религиозного менталитета (имевших место в старообрядческой жизни на чужбине - в Турции, Китае, Бразилии) (Шемякин, Шемякина, 2012: 110-117) мы увидели почти сплошь ассимиляционные процессы - притом весьма травматичные. Безусловно, в средах аляскинских поповцев и беспоповцев эти процессы весьма различаются. Ассимиляция, доходящая до нелепой подражательности, и почти полная утрата родной речи и традиционного уклада свойственны поповцам Николаевска на Аляске в большей мере, чем их бывшим одноверцам с южного Кеная. Причина - в динамической напряженности и ослаблении негативной идентичности, свойственной «классическим» старообрядцам. Архаичный образ жизни, «воинствующий антиинтеллектуализм» (Рябцев, 2007: 17), знаменитое староверческое начетничество (в смысле: «принципиальное 
буквоедство») (Адрианова-Перетц, 1941: 85-87), агрессивная патриархальность и тотальное отрицание «грехопадшего мира сего» (раскольничество, в смысле «сектантство») - эти детали «классического» древлеправославия всегда являлись сдерживающим механизмом, препятствующим утрате собственной идентичности (Товбин, 2014b: 78-82). Аогичным было бы увидеть в старообрядческой среде Америки образ жизни, напоминающий поведение амишей или меннонитов. Однако старообрядческая среда Аляски столь быстро модернизировалась и секуляризовалась, что по динамике вовлеченности в «мир сей» заметно обгоняет даже диаспоры современного, новообрядческого православия - греков и сербов. Напрашивается поиск той детали, которая позволила староверам начать столь стремительно ассимилироваться, прикрывая секуляризационные процессы наружной и примитивной мимикрией под традиционность. Судя по всему - однако наша гипотеза еще ждет уточнений, - речь идет именно о государственническом векторе православия в целом. Если «византистское» православие ${ }^{7}$ - православие Кирилла Александрийского, Иосифа Волоцкого и Аимитрия Ростовского - предполагает «душеспасительный» сервилизм в отношении к государству, то древлеправославие («раскольничество») - формат Иоанна Златоуста, Нила Сорского и Аввакума - является «теневым», негативно и критично зависящим от государства, но никак не самостоятельным (Товбин, 2014а: 73-75). Таким образом, для православного христианина государство является одним из важнейших акторов его смыслополагания в земной и даже загробной жизни (Тихомиров, 2008: 9-22). Аибо подчиняясь «всяким властям от Бога» (Рим., 13: 1-2), либо доказывая отсутствие этой взаимозависимости, строит свою духовную жизнь православный верующий (Кузнецов, 2013: Электронный ресурс). США подарили староверам иную систему координат, в которой государство сдвинуто на периферию сознания. Оно не может дать огромных и долговременных льгот: так, органы государственной власти благодетельствовали старообрядческому поселению на Аляске, но затем легко свернули рыболовецкие льготы, чем обрекли сложившуюся экономику Николаевска на развал и перестройку. С другой стороны, частная жизнь гражданина США автономна; государство принципиально не вмешивается в область взглядов и верований, снижая до нуля необходимость сопротивляться ему как «антихристову учреждению». Государство в США строит отношения с отдельным активным индивидом, предлагая взаимовыгодные условия, напрямую зависящие от ментальной секуляризации и автономизации этого индивида. Аиаспора для политэкономической системы США представляет интерес, только если выступает как хозяйственный субъект в условиях современной постиндустриальной экономики. В этом - отличие и от политически выгодного автономизма, на условиях которого проживали староверы в Турции и Китае, и от отстающей аграрной экономики Аатинской Америки, давшей возможности для привычного старообрядцам труда и образа жизни.

В связи с конфессиональным отпочкованием от основной старообрядческой среды обеих Америк насельники Николаевска были вынуждены более интенсивно интегрироваться в экономическую и социальную сферы светских США, что и привело к значимым социальным инверсиям. Напрашивается вывод о зависимости экономического процветания николаевцев от их постепенной ассимиляции в светском пространстве - возможно, с соблюдением поверхностной русско-старообрядческой стилистики повседневности.

Аанный очерк не является окончательным и исчерпывающим описанием аляскинской старообрядческой ментальности - надеемся, работа будет продолжена как в последующих компаративных обобщениях, так и в новых экспедициях. 


\section{ПРИМЕЧАНИЯ}

1 Толстовский фонд (Tolstoy Foundation) был создан в 1939 г. дочерью $\Lambda$. Н. Толстого Александрой Толстой для помощи в эмиграции из России общин, преследуемых властями по религиозным соображениям. За столетие своей деятельности фонд содействовал переселению в США в конце XIX в. больших групп русских молокан, субботников, хлыстов и пятидесятников, а во второй половине $\mathrm{XX}$ в. - старообрядцев.

2 Боро - административно-территориальная единица на Аляске и в Канаде, нечто среднее между областью и районом.

3 Белокриницкая иерархия - «Аревлеправославная Церковь Христова белокриницкой иерархии»- возникшая в XIX в. в Австрии автономная старообрядческая церковная структура с полноценной трехчинной иерархией духовенства, образовавшаяся вследствие присоединения к старообрядческому беглопоповскому сообществу греческого митрополита Амвросия (Поповича). С того времени «белокриницких» староверов именовали поповцами, а не присоединившихся к этой церкви - беглопоповцами (они создали в 1920-е годы собственную церковную структуру - «новозыбковскую иерархию» - «Аревлеправославную Церковь»). «Белокриницкие» и «новозыбковские» - два направления староверов-поповцев.

4 «Американа» - бытовое понятие, введенное Ф. Фукуямой. Означает весь комплекс повседневной культуры, быта, жизненного уклада и менталитета обычных американцев (см.: Фукуяма, 2003).

5 County - автономная сельская община в англоязычных странах. Полноценного русскоязычного аналога нет.

6 Рурализация (иначе: рурилизация или рурификация) - современная тенденция в постиндустриальных странах к переносу производственного пространства граждан на дом, переселение из многоквартирных домов в индивидуальные, из городов - в пригороды и села. Противоположность индустриальной урбанизации.

7 Византизм (византинизм) - церковно-государственное соотношение ( «симфония») в поздней Римской империи - Византии, характеризующееся всемерным контролем государя за деятельностью церкви, превращение церкви в элемент бюрократического аппарата. С другой стороны - сакрализация церковью деятельности и личности государя и провозглашение участия государя и государства в деле спасения христианина. В данном случае термин употреблен в кавычках, так как при Кирилле Александрийском (в Риме) и Иосифе Волоцком (в Московской Руси) византизм еще только намечал свое развитие, благодаря идеологии и деятельности названных святителей. При Аимитрии Ростовском византизм уже имел высокий градус развития - синодальную политику Петра I.

\section{СПИСОК АИТЕРАТУРЫ}

Адрианова-Перетц, В. П. (1941) Старообрядческая литература XVIII века // История русской литературы : в 11 т. / ред.: В. А. Аесницкий, Б. С. Мейлах, А. А. Плоткин. М. : ИзА-во АН СССР. Т. 4. Ч. 2. 533 с.

Аргудяева, Ю. В. (2012) Эмиграция русских старообрядцев-дальневосточников в Китай и Северную Америку // Религиоведение. № 2. С. 9-20.

Аргудяева, Ю. В. (2014а) Потомки русских казаков-старообрядцев в Турции и Северной Америке // Религиоведение. № 3. С. 46-61.

Аргудяева, Ю. В. (2014b) Русские старообрядцы в Южной Америке // Религиоведение. № 1. C. 76-93.

Аргудяева, Ю. В., Хисамутдинов, А. А. (2013) Из России через Азию в Америку: русские старообрядцы. Владивосток : Аальнаука. 428 с.

Гортер, В. Т. (2015) Ао Бога высоко, до царя далеко! Заметки по итогам путешествия на Аляску // Наследие святителя Иннокентия (Вениаминова) и православная миссионерская деятельность в Сибири, на Аальнем Востоке и сопредельных территориях : материалы II научной практ. конф. 15 мая 2015 г. / отв. ред. С. Г. Ступин, науч. ред. С. В. Мельникова. Иркутск : 
Изд-во Иркутск. обл. гос. универс. науч. библ. им. И. И. Молчанова-Сибирского. 224 с. С. $152-171$.

Злобин, А. (2005) Русские барбудос: старообрядцы часовенного согласия в Уругвае // Старообрядецъ (газета). №33. С. 23.

Калугина, С. Г. (2009) История Николаевска // Зеньковский, С. А. Русское старообрядчество / ред. В. В. Нехотин. М. : Институт АИ-АИК ; Квадрига. 688 с. С. 679-687.

Кузнецов, Ф. С. (2013) Об отношении древлеправославной Старообрядческой церкви к Верховной Советской Власти [Электронный ресурс] // Книжица Самарского староверия. URL: http://samstar-biblio.ucoz.ru/publ/137-1-0-1208 (дата обращения: 08.06.2016).

Моррис, Р. А., Моррис (Юмсунова), Т. Б. (2009) Русские староверы на Аляске // Вестн. Бурят. гос. ун-та. Вып. 10. С. 115-122.

Попова, О. В. (2015) Трансформация этнокультурных систем старообрядческих общин в зарубежных странах // Вестн. Оренбург. гос. ун-та. Вып. 7 (182). С. 173-181.

Рябцев, А. Ю. (2007) Когда простота хуже воровства. Старообрядческой церкви нужны дискуссии, а не благостная тишина // НГ-Религии. 7 ноября. С. 17.

Софроний (Ииполит), архиеп. (1999) Орегон. Соединенные Штаты Америки // Русь православная : изд. Совета съезда мирян древлеправославных общин Приморского края РПСЦ. Вып. 2. С. 6.

Теплоухова, М. В. (2013) Восстановление беспоповской старообрядческой общины Приморья: предварительные итоги // Известия Иркутск. гос. ун-та. Сер. Политология. Религиоведение. Вып. 2 (11). Ч. 2. С. 258-269.

Тихомиров, А. А. (2008) Единоличная власть как принцип государственного строения. С. 9-167 // Тихомиров, А. А. Руководящие идеи русской жизни / ред. О. А. Платонов. М. : Институт русской цивилизации. 640 с.

Товбин К. М. (2014а) Концепция «Москва - третий Рим» в русском православном старообрядчестве. СПб. : Археодоксія. 94 с.

Товбин К. М. (2014b) Пострелигия и ее становление в русском старообрядчестве. М. : Этносоциум. 486 с.

Фефелов, К. С., свящ., Гашкова, Н. (1999) Николаевск на Аляске // Русь православная : изд. Совета съезда мирян древлеправославных общин Приморского края РПСЦ. Вып. 2. С. 5.

Фукуяма, Ф. (2003) Великий разрыв : пер. с англ. / под общ. ред. А. В. Александровой. М. : ACT. 476 c.

Хисамутдинов, А. А. (2011) Старообрядцы: из России в Америку через Китай // Вопросы истории. № 7. С. 90-102.

Хисамутдинов, А. А. (2015) Русская Аляска и православие. Владивосток : Изд-во Аальневост. ун-та. 55 с.

Шемякин, Я. Г., Шемякина, О. А. (2012) Конфессия-изолят как цивилизационная альтернатива // Общественные науки и современность. № 2. С. 110-125.

Аата поступления: 08.06.2016 2.

OLD BELIEVERS FROM NIKOLAEVSK-ON-ALASKA:

ADAPTATION OR ASSIMILATION IN THE SECULAR LIFE OF THE USA?

K. M. TOVBIN

(YuZHNo-SakHalinsk BRANCH, PLEKHANOV RUSSIAN UNIVERSITY of ECONOMICS),

A. V. SEMICHAEVSKY

(Central City Library, Yuzhno-SakHalinsk),

V. V. SOKOLOV

(INDEPENDENT RESEARCHER, YUZHNO-SAKHALINSK)

Russian Old Believers are one of the most striking phenomena of Russian traditional culture, and in this respect have been the subject of numerous studies. However, few of them have been focused on 
emigrant Old Believers - a unique example of how traditional Russian culture adapts to completely alien conditions of a new cultural space. Today, the Old Believers of Alaska are an example of adapting traditional spiritual principles to living in the world of globalization, westernization, scientific and technological progress and post-industrialism. Old Believers' experience of non-aggressive resistance to the world order which erases ethnic, cultural and religious distinctions is extremely important for understanding the trajectory of Russian culture today.

The aim of this article is to provide a comprehensive study of the worldview and lifestyle of Old Believers in Alaska. In October 2015, an expedition examined the close intertwining of residual traditionalism, liberalizing social sphere and radical modernist mentality in Old Believer communities. This led us to suggest that traditional Orthodoxy may prove helpless before the onslaught of the reality of secular America. The article compares the experience of Old Believers' in Nikolaevsk with that of the Bespopovtsy of Southern Alaska who have had more success in preserving their identity, but also succumbing to the secularizing influence of the culture of everyday life in the USA.

Our study revealed not only the cultural and spiritual decline of Alaskan Old Believers, but also the power of American consumerism which dissolves the specific character of immigrant diasporas, at the same time preserving and increasing the multiplicity of original subcultures in the USA.

Keywords: Old Belief Orthodoxy; Old Believers; Russian Orthodoxy; diaspora; USA; Alaska; Nikolaevsk; Kenai Peninsula; adaptation; assimilation

\section{REFERENCES}

Adrianova-Peretts, V. P. (1941) Staroobriadcheskaia literatura XVIII veka. In: Istoriia russkoi literatury : in 11 vols., ed. by V. A. Desnitskii, B. S. Meilakh, L. A. Plotkin. Moscow, Izd-vo AN SSSR. Vol. 4, Pt. 2.533 p. (In Russ.)

Argudiaeva, Yu. V. (2012) Emigratsiia russkikh staroobriadtsev-dal'nevostochnikov v Kitai i Severnuiu Ameriku. Religiovedenie, no. 2, pp. 9-20. (In Russ.)

Argudiaeva, Yu. V. (2014a) Potomki russkikh kazakov-staroobriadtsev v Turtsii i Severnoi Amerike. Religiovedenie. No. 3, pp. 46-61. (In Russ.)

Argudiaeva, Yu. V. (2014b) Russkie staroobriadtsy v Yuzhnoi Amerike Religiovedenie. No. 1, pp. 76-93. (In Russ.)

Argudiaeva, Yu. V., Khisamutdinov, A. A. (2013) Iz Rossii cherez Aziiu v Ameriku: russkie staroobriadtsy. Vladivostok, Dal'nauka Publ. 428 p. (In Russ.)

Gorter, V. T. (2015) Do Boga vysoko, do tsaria daleko! Zametki po itogam puteshestviia na Aliasku. In: Nasledie sviatitelia Innokentiia (Veniaminova) $i$ pravoslavnaia missionerskaia deiatel'nost' $v$ Sibiri, na Dal'nem Vostoke $i$ sopredel' nykb territoriiakb : materialy II nauch.-prakt. konf. 15 maia 2015 g., ed. by S. G. Stupin and S. V. Mel'nikova. Irkutsk, Izd-vo Irkutsk. obl. gos. univers. nauch. bibl. im. I. I. Molchanova-Sibirskogo. 224 p. Pp. 152-171. (In Russ.)

Zlobin, A. (2005) Russkie barbudos: staroobriadtsy chasovennogo soglasiia v Urugvae. Staroobriadets, no. 33, p.23. (In Russ.)

Kalugina, S. G. (2009) Istoriia Nikolaevska. In: Zen'kovskii, S. A. Russkoe staroobriadchestvo, ed. by V. V. Nekhotin. Moscow, Institut DI-DIK; Kvadriga. 688 p. Pp. 679-687. (In Russ.)

Kuznetsov, F. S. (2013) Ob otnoshenii drevle-pravoslavnoi Staroobriadcheskoi tserkvi $k$ Verkbovnoi Sovetskoi Vlasti [online] Knizhitsa Samarskogo staroveriia. Available at: http://samstar-biblio.ucoz.ru/publ/137-1-0-1208 (access date: 08.06.2016). (In Russ.)

Morris, R. A., Morris (Yumsunova), T. B. (2009) Russkie starovery na Aliaske. Vestnik Buriatskogo gosudarstvennogo universiteta. Iss. 10, pp. 115-122. (In Russ.)

Popova, O. V. (2015) Transformatsiia etnokul'turnykh sistem staroobriadcheskikh obshchin v zarubezhnykh stranakh. Vestnik Orenburgskogo gosudarstvennogo universiteta. Iss. 7 (182), pp. 173-181. (In Russ.)

Riabtsev, A. Yu. (2007) Kogda prostota khuzhe vorovstva. Staroobriadcheskoi tserkvi nuzhny diskussii, a ne blagostnaia tishina. NG-Religii. November 7, p. 17. (In Russ.) 
Sofronii (Lipolit), arkhiep. (1999) Oregon. Soedinennye Shtaty Ameriki. In: Rus' pravoslavnaia : izd. Soveta s'ezda mirian drevlepravoslavnykh obshchin Primorskogo kraia RPSTs. Iss. 2, p. 6. (In Russ.)

Teploukhova, M. V. (2013) Vosstanovlenie bespopovskoi staroobriadcheskoi obshchiny Primor'ia: predvaritel'nye itogi. Izvestiia Irkutskogo gosudarstvennogo universiteta. Ser. Politologiia. Religiovedenie. Iss. 2 (11), pt. 2, pp. 258-269. (In Russ.)

Tikhomirov, L. A. (2008) Edinolichnaia vlast' kak printsip gosudarstvennogo stroeniia. In: Tikhomirov, L. A. Rukovodiashchie idei russkoi zhizni, ed. by O. A. Platonov. Moscow, Institut russkoi tsivilizatsii. 640 p. Pp. 9-167. (In Russ.)

Tovbin, K. M. (2014a) Kontseptsiia «Moskva - tretii Rim» v russkom pravoslavnom staroobriadchestve. St. Petersburg, Arkheodoksiia. 94 p. (In Russ.)

Tovbin, K. M. (2014b) Postreligiia i ee stanovlenie v russkom staroobriadchestve. Moscow, Etnosotsium. 486 p. (In Russ.)

Fefelov, K. S. (rev.), Gashkova, N. (1999) Nikolaevsk na Aliaske. In: Rus' pravoslavnaia : izd. Soveta s'ezda mirian drevlepravoslavnykh obshchin Primorskogo kraia RPSTs. Iss. 2, p. 5. (In Russ.)

Fukuyama, F. (2003) Velikii razryv. Moscow, AST. 476 p. (In Russ.)

Khisamutdinov, A. A. (2011) Staroobriadtsy: iz Rossii v Ameriku cherez Kitai. Voprosy istorii, no. 7, pp. 90-102. (In Russ.)

Khisamutdinov, A. A. (2015) Russkaia Aliaska i pravoslavie. Vladivostok, Izd-vo Dal'nevost. un-ta. 55 p. (In Russ.)

Shemiakin, Ya. G., Shemiakina, O. D. (2012) Konfessiia-izoliat kak tsivilizatsionnaia al'ternativa. Obshchestvennye nauki i sovremennost', no. 2, pp. 110-125. (In Russ.)

Submission date: 08.06 .2016$.

Товбин Кирилл Михайлович - кандидат философских наук, доцент Южно-Сахалинского института Российского экономического университета им. Г. В. Плеханова, член Российского философского общества, лектор общества «Знание». Адрес: 693007, Россия, г. Южно-Сахалинск, просп. Победы, А. 68. Тел.: +7 (4242) 222-038. Эл. алрес: kimito@yandex.ru

Семичаевский Артемий Викторович - специалист Центральной городской библиотеки им. О. П. Кузнецова. Адрес: 693000, Россия, г. Южно-Сахалинск, ул. Аенина, А. 244. Тел.: +7 (4242) 724-233. Эл. адрес: arsem-86@yandex.ru

Соколов Валентин Валентинович - независимый исследователь. Адрес: 693000, Россия, г. Южно-Сахалинск, ул. Есенина, А. 5, кв. 20. Тел.: + 7 (914) 086-88-94. Эл. адрес: falcon8282@ mail.ru

Tovbin Kirill Mikhailovich, Candidate of Philosophy, Associated Professor, Yuzhno-Sakhalinsk branch, Plekhanov Russian University of Economics; Member, Russian Philosophical Society; Lecturer, Znanie Society. Postal address: 68 Pobedy Ave, Yuzhno-Sakhalinsk, Russian Federation 693007. Tel.: +7 (4242) 222-038. E-mail:kimito@yandex.ru

Semichaevsky Artemiy Viktorovich, Specialist, O.P. Kuznetsov Central City Library, YuzhnoSakhalinsk. Postal address: 244 Lenin St., Yuzhno-Sakhalinsk, Russian Federation 693012. Tel.: +7 (4242) 724-233. E-mail: arsem-86@yandex.ru

Sokolov Valentin Valentinovich, independent researcher. Postal address: Apt. 20, 5 Esenina St, Yuzhno-Sakhalinsk, Russian Federation 693000. Tel.: + 7 (914) 086-88-94. E-mail: falcon8282@ mail.ru 